\title{
Characterization of the Natural Fragmentation of Explosive Ord- nance Using the Numerical Techniques Based on the FEM
}

\author{
Marinko Ugrčici ${ }^{1)}$ \\ Miodrag Ivanišević ${ }^{2)}$
}

\begin{abstract}
The presented new methodology for full numerical simulating performances of casing rupture integrates the finite element method and the stochastic failure theory in the solvers for 2D and 3D axis-symmetric analyses of the projectile fragmentation. This paper focuses on the effects of the type of casing on the fragmentation characteristics. In this way, the selected specimen considers three specific types of high explosive (HE) items: 105 mm HE projectile M1, 120 mm HE mortar shell M62 and 128 mm HE missile warhead M63. As well, the presented technique makes it possible to consider the effects of the mechanical properties of the casing material and explosive type on the fragmentation. The results of numerical simulation and some relevant experimental data are used for their comparative analysis and evaluation of the numerical approach, confirming the computed parameters of fragmentation predict properly the characteristics of the natural casing disruption.
\end{abstract}

Key words: high explosive projectile, projectile fragmentation, numerical simulation, finite element method.

\section{Introduction}

$\mathrm{R}$ EAL dynamic systems and phenomena have always been of interest to humankind, but only in the middle of the last millennium there have been made serious steps in their mathematical interpretation. The modern theory of dynamical systems has a relatively short history, and seeks to provide answers on two important aspects of the integrity of dynamical systems: structural integrity and integrity of the dynamical processes, which sub-diversities are still very different (e.g., various aspects of the stability of dynamical systems). The development of the theory of dynamical systems integrity was in many ways based on the appropriate mathematical theory of phenomenology and phenomenological mapping of different physical systems and processes. An important contribution to a systematic approach and formulation of the mathematical theory of phenol-menology, in his works [1,2], was given by Mihailo Petrović to whom these lines are dedicated. In the context of the integrity of dynamical systems considered as well in more details in [3], this paper deals with the explosion of HE projectiles where structural integrity and fracture mechanics are of a primary interest.

Relating to the casing, an explosion of the HE projectile or HE warhead is always followed by shock loading and fragmentation effects and a response of these explosive propulsive systems involves highly non-linear phenomena of a transient nature. Regarding the theoretical consideration, there are three basic theoretical approaches that can be applied in order to accurately characterize such events, together with more general skills such as experience and judgments. Firstly, empirical formulas (hand calculations) can be applied. However, only the simplest highly idealized problems are practically solvable. Secondly, more complex analytical techniques, which are usually computer-based or involve the use of look-up tables and graphs, are very useful in enabling consideration of many different cases, relatively quickly. However, the analytical techniques are based on a limited set of experimental data and particular simplified assumptions, so that are only applicable to a relatively narrow range of problems.

Finally, the numerical software based on the finite elements method (FEM) enables to model the full physics of the phenomena and offers another approach to the fragmentation studies. They are designed to solve the governing conservation equations that describe the behavior of the considered physical system. By their nature, numerical techniques are suitable for solving a wider range of problems than any particular analytical technique. As well, they allow very different results analyses of a perfectly instrumented numerical experiment. Thus the parameters such as stress and strain, strain rate, temperature, etc., that are virtually impossible to measure in the real experiments can be examined in whatever appropriate detail. However, the numerical techniques for these highly non-linear phenomena are not able to model the complete physics without the required data which must be obtained through the experiments (e.g., material properties).

The analytical techniques of fragmentation analysis can be the statistical and the physically based approaches [4]. The statistical modeling is based on the analysis of experimental data used in the definition of the mathematical description of the distribution of size, mass and shape of fragments. In a large number of papers [5-11] the authors deal with different statistical models of the fragments distribution. On the other hand, the authors have considered the physical approach to the fragmentation process based on the classical study of Mott [12]. The well-known Mott's initial fragmentation model was the basis for more complex research approaches to the modeling of fragmentation $[5,9,10]$. The calculation of fragmentation characteristics presented in the above-mentioned works apply specifically to the cylindrical models or to the real casings that can be reasonably approximated

\footnotetext{
1) Mathematical Institute SASA, Kneza Mihajla 36, 11000 Belgrade, SERBIA

2) Military Technical Institute (VTI), Ratka Resanovića 1, 11132 Belgrade, SERBIA

Correspondence to: Marinko Ugrčić; e-mail: ugrcicmarinko@gmail.com
} 
as either particular hollow cylindrical bodies or a series of hollow cylindrical sections [7,9-11]. If the variation in the wall thickness-to-diameter casing ratio is slight, the fragmentation characteristics may be calculated using average values over the entire length of the casing. However, if the variations are large, the casing is treated as a series of equivalent cylinders representing the actual shape as closely as possible. This principle, adopted on $105 \mathrm{~mm}$ M1 HE projectile casing [13], is illustrated in [10]. Generally, for this kind of fragmentation analysis, it is important to obtain the best mapping (description) of the casing that is available. It can be achieved using the iteration procedure, providing the errors of the masses of the explosive charge and casing are less than $0.1 \%$.

It should be noted that the base of the projectile is not a part of the hollow cylindrical shape and the fragmentation characteristics of the base may not be determined using the equations described in the above listed references. Similarly, the fuze body may usually not contain the explosive material and, if this is the case, the fragments from this region may not be characterized by the methods described above. A qualitative improving in the consideration of fragmentation represents a sophisticated physically based approach developed in [14]. The given model links highstrain and high-strain-rate continuum hydrocode analyses with a series of fragmentation modeling routines enabling the accurate numerical simulation of performance of natural and controlled casing fragmentation [15].

\section{Applied methods and models}

For the purpose of this work, summarizing all the above considered advantages and disadvantages of the analytical and numerical techniques, the numerical method was chosen for the fragmentation study. The software tools ANSYS AUTODYN-2D ${ }^{\circledR}$ and AUTODYN-3D ${ }^{\circledR}$ [16], based on the FEM, were used in the characterization of the natural fragmentation. As well, the representative specimen was selected so it includes three specific types of the real HE items of the narrow caliber range (105 to $128 \mathrm{~mm}$ ): HE projectile, HE mortar shell and HE warhead; shown in Fig.1.

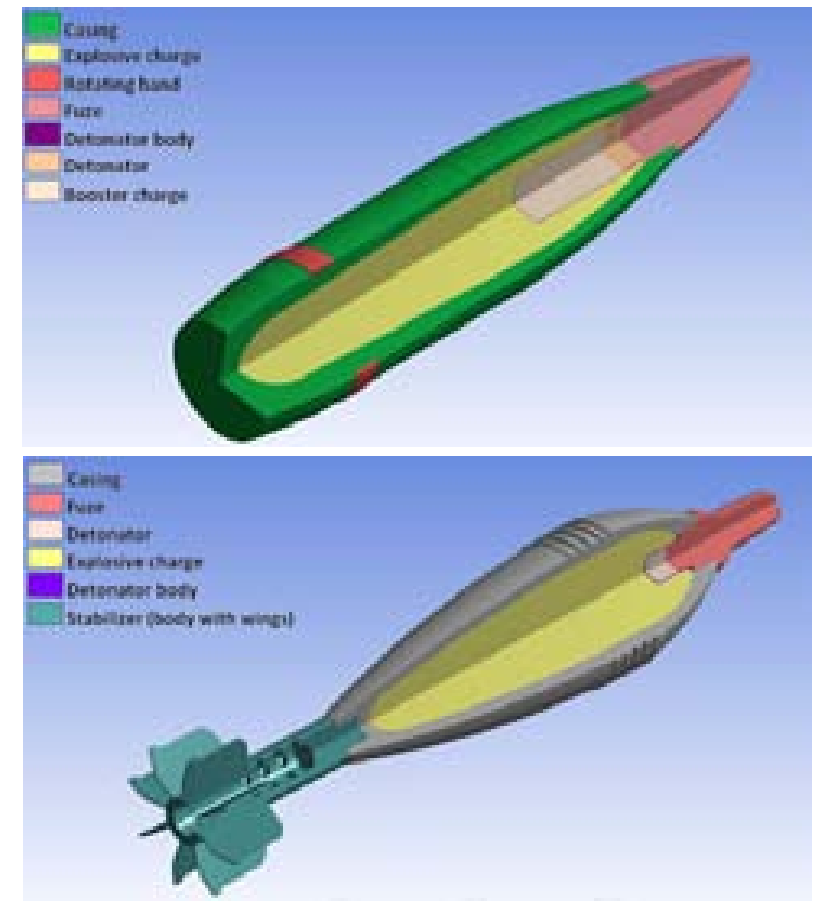

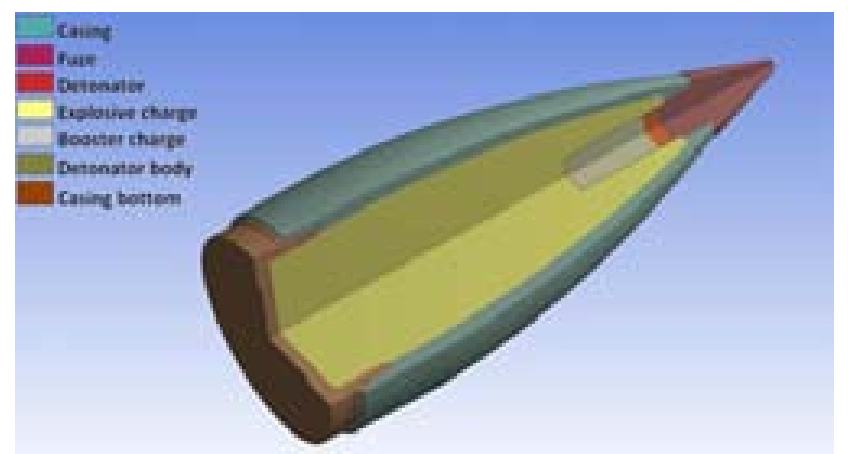

Figure 1. Three-quarter axial cross-sections of $105 \mathrm{~mm}$ HE projectile M1 (top), $120 \mathrm{~mm}$ HE mortar shell M62 (middle) and $128 \mathrm{~mm}$ HE warhead M63 (bottom)

The goal activities of the research presented in this work can be summarized as follows:

- Numerical simulation of the fragmentation of all mentioned specific types of the HE items, determining the main characteristics of fragmentation and comparative analysis of the numerical and experimental results of the fragmentation with general evaluation of the chosen predictive numerical technique; and

- Determining some practically immeasurable fragmentation parameters such as the stress and strain, temperature and strain rate in the considered materials.

\section{Material properties}

In the numerical experiments of HE projectiles fragmentation the various mechanical characteristics of the steel casing are used. The main mechanical properties of the casing materials are shown in Table 1.

Table 1. Mechanical parameters of casing materials

\begin{tabular}{||c|c|c|c|c|c|c|c||}
\hline \multirow{2}{*}{ Label } & Density & $\begin{array}{c}\text { Elastic } \\
\text { limit }\end{array}$ & $\begin{array}{c}\text { Young's } \\
\text { Modulus }\end{array}$ & $\begin{array}{c}\text { Poison's } \\
\text { ratio }\end{array}$ & $\begin{array}{c}\text { Shear } \\
\text { modulus }^{\mathrm{a}}\end{array}$ & $\begin{array}{c}\text { Fracture } \\
\text { stress }\end{array}$ & $\begin{array}{c}\text { Fracture } \\
\text { strain }\end{array}$ \\
\cline { 2 - 8 } & $\rho$ & $\sigma_{v}$ & $E$ & $v$ & $G$ & $\sigma_{F}$ & $\varepsilon \mathrm{F}$ \\
\hline Steel \#0 & 4000 & 510 & 210.0 & 0.30 & 80.769 & 810 & 0.210 \\
\hline Steel \#1 & 7830 & 580 & 220.0 & 0.28 & 85.938 & 810 & 0.210 \\
\hline Steel \#2 & 7850 & 324 & 210.0 & 0.29 & 81.395 & 589 & 0.230 \\
\hline Steel \#3 & 7800 & 920 & 220.0 & 0.28 & 85.938 & 1000 & 0.205 \\
\hline Steel \#4 & 7850 & 495 & 210.0 & 0.29 & 81.395 & 785 & 0.213 \\
\hline
\end{tabular}

a Shear modulus: $G=E / 2(1+v)$.

Let us say that a complex artillery fuze design was very simplified and modeled as a homogenous steel body with $4000 \mathrm{~kg} / \mathrm{m}^{3}$ of artificial density (Steel \#0). This is suitable in this kind of analyses without the negative repercussions on the accuracy of the results. As well, all necessary data for energetic materials (explosives: TNT and Comp. B) and metals (Copper/Johnson Cook, used for rotating band) are given in the solver material library.

The HE items were modeled based on the accepted mechanical properties of the materials and the design geometry. The computed masses of the appropriate parts together with the number of generated finite elements for full threedimensional models of each item are given in Table 2 .

Data given in Table 2 were used to calculate the mass of metallic parts, explosive and fuze. Their computed mass and appropriate real mass, shown in Table 3, coincide well. 
Table 2. Computed parameters of the components of the HE items

\begin{tabular}{|c|c|c|c|c|c|c|c|c|c|}
\hline \multirow[b]{2}{*}{ Part } & \multicolumn{3}{|c|}{105 mm HE projectile } & \multicolumn{3}{|c|}{120 mm HE mortar shell } & \multicolumn{3}{|c|}{128 mm HE warhead } \\
\hline & Material & $\begin{array}{c}\text { Mass } \\
\text { m }\end{array}$ & Number of FE & Material & $\begin{array}{c}\text { Mass } \\
\text { m }\end{array}$ & Number of FE & Material & $\begin{array}{c}\text { Mass } \\
\text { m }\end{array}$ & $\begin{array}{c}\text { Number of } \\
\text { FE }\end{array}$ \\
\hline- & - & $\mathrm{kg}$ & - & - & $\mathrm{kg}$ & - & - & $\mathrm{kg}$ & - \\
\hline Casing & Steel \#1 & 11.532 & 1824732 & Steel\#2 & 8.506 & 1216614 & Steel \#4 & 4.611 & 1358392 \\
\hline Rotating band & Copper & 0.212 & 31488 & l & I & I & I & I & / \\
\hline Explosive charge & TNT & 2.036 & 65352 & TNT & 2.283 & 7050 & TNT & 2.412 & 154078 \\
\hline Fuze (body) & Steel \#0 & 0.823 & 25340 & Steel \#0 & 0.436 & 35990 & Steel \#0 & 0.156 & 139910 \\
\hline Detonator & TNT & 0.044 & 11356 & TNT & 0.023 & 6878 & $\mathrm{TNT}$ & 0.030 & 64 \\
\hline Booster charge & TNT & 0.212 & 33212 & I & I & l & TNT & 0.042 & 12228 \\
\hline Detonator body & Al aloy & 0.064 & 1956 & Steel \#3 & 0.024 & 7608 & Steel \#3 & 0.018 & 12624 \\
\hline Stabilizer body & / & / & l & Steel \#3 & 0.991 & 55670 & l & / & l \\
\hline Wing (All) & I & I & l & Steel \#3 & 0.296 & 25624 & I & I & I \\
\hline Casing bottom & 1 & 1 & 1 & 1 & 1 & 1 & Steel \#4 & 1.348 & 1516194 \\
\hline Sum & - & 14.923 & 1993436 & - & 12.559 & 1355434 & - & 8.618 & 3193490 \\
\hline
\end{tabular}

Table 3. Review of the computed and real masses of the HE items

\begin{tabular}{||c|c|c|c|c||}
\hline \multicolumn{2}{|c|}{} & \multicolumn{3}{c||}{ Computed mass (Real mass) } \\
\cline { 2 - 5 } \multicolumn{2}{|c|}{ Part } & $\begin{array}{c}105 \mathrm{~mm} \mathrm{HE} \\
\text { projectile }\end{array}$ & $\begin{array}{c}120 \mathrm{~mm} \text { HE mortar } \\
\text { shell } \\
\text { with stabilizer }\end{array}$ & $\begin{array}{c}128 \mathrm{~mm} \text { HE } \\
\text { warhead }\end{array}$ \\
\hline \hline & - & $\mathrm{kg}$ & $\mathrm{kg}$ & $\mathrm{kg}$ \\
\hline$(1)$ & $\begin{array}{c}\text { Metallic compo- } \\
\text { nents }\end{array}$ & $\begin{array}{c}12.631 \\
(12.738)\end{array}$ & $10.253(10.100)$ & $6.133(6.141)$ \\
\hline$(2)$ & Explosive & $2.292(2.217)$ & $2.306(2.500)$ & $2.484(2.514)$ \\
\hline$(3)$ & Fuze & $0.931(0.957)$ & $0.483(0.460)$ & $0.246(0.260)$ \\
\hline$(4)$ & $\begin{array}{c}\text { Total mass } \\
(4)=(1)+(2)\end{array}$ & $\begin{array}{c}14.923 \\
(14.955)\end{array}$ & $12.559(12.600)$ & $8.618(8.655)$ \\
\hline
\end{tabular}

\section{Finite element modeling}

The $120 \mathrm{~mm}$ HE mortar shell was used to illustrate the applied modeling technique. The air and explosive materials are modeled using the Euler solver where it is able to treat multi-material effects in one finite elements mesh. The Lagrangian meshing was used to describe the behavior of projectile metallic parts. The generated 2D Euler mesh in Fig.2 (top) is uniform and fine sizing with $1 \times 1 \mathrm{~mm}$ cells dimensions. The same figure (bottom) depicts the 3D Euler meshing with a centered grade zoning of min. $2 \times 2$ $\mathrm{mm}$ cell dimensions. As well, here are shown the remapped (2D to 3D) Euler explosive parts and initial coupled Lagrange-Euler meshing with the inserted geometry of the $120 \mathrm{~mm}$ HE mortar shell modeled in the pre-processing procedure.
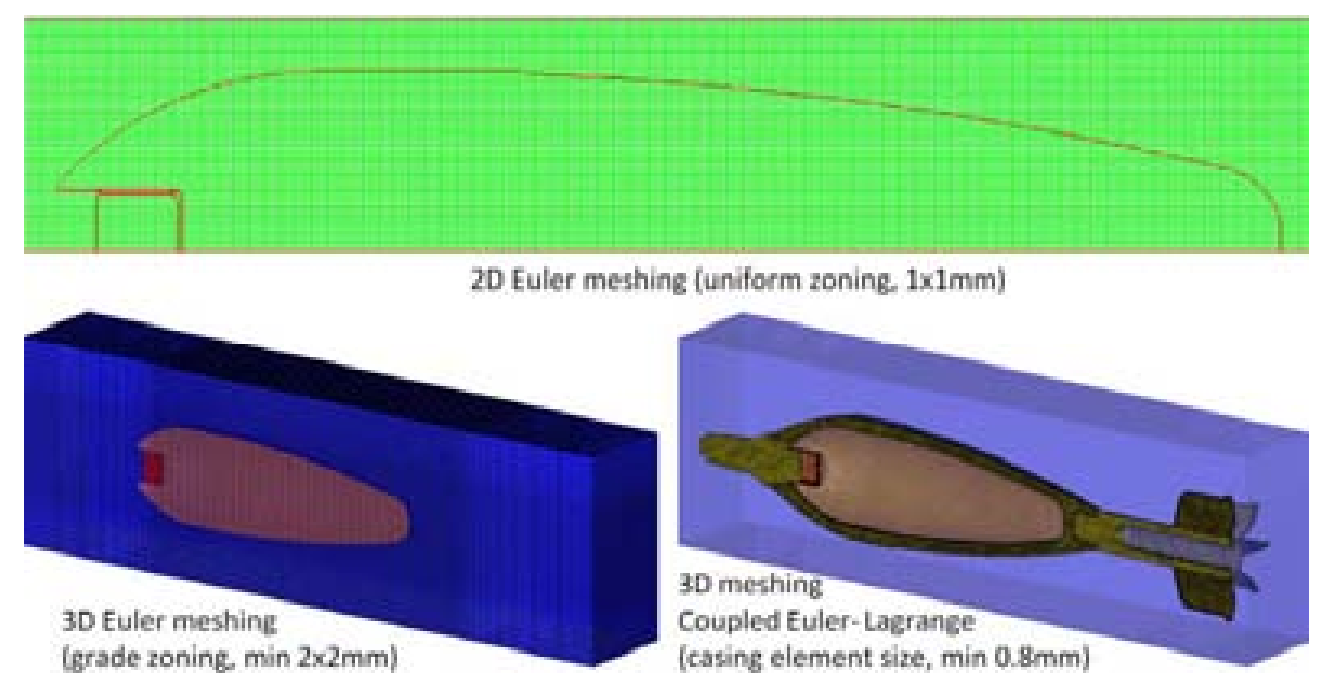

Figure 2. The FEM modeling applied on the $120 \mathrm{~mm}$ HE mortar shell

After the initial studying and partial testing, convenient ways of pre-processing and numerical simulation were chosen. Firstly, the metallic parts design and meshing were achieved using CAD/CAE tools and two ANSYS solvers: design modeler and finite element modeler. Finally, after materials definition and assignment of the appropriate initial and boundary conditions, the designed models were remapped into the solver AUTODYN. The half 2D and half 3D axissymmetry FE models were adopted for the simulation.

\section{Theoretical considerations}

Before the solution is initiated, a brief review of the constitutive equations and equations of state (EOS) for all materials will be discussed.

\section{Governing equations}

The partial differential equations express the conservation of mass, momentum and energy in the Lagrangian coordinates 
$[16,17]$. These, together with the equations of state (material models) $[16,18]$ and a set of initial and boundary conditions, define the complete solution of the problem. Material continuum associated with a Lagrangian zone stays with that zone under any deformation. Thus a Lagrangian grid moves and distorts during time with the material automatically satisfying the conservation of mass. The density $\rho$ at any time can be determined from the current volume $V$ of the zone and its initial mass $m_{0}$ :

$$
\rho=\frac{\rho_{0} V_{0}}{V}=\frac{m_{0}}{V}
$$

where is: $\rho_{0}$ - initial density and $V_{0}$ - initial volume.

Then, the partial differential equations which express the conservation of momentum relate the acceleration and stress tensor $\sigma_{i j}$ :

$$
\left.\begin{array}{l}
\rho \ddot{x}=\frac{\partial \sigma_{x x}}{\partial x}+\frac{\partial \sigma_{x y}}{\partial y}+\frac{\partial \sigma_{x z}}{\partial z} \\
\rho \ddot{y}=\frac{\partial \sigma_{y x}}{\partial x}+\frac{\partial \sigma_{y y}}{\partial y}+\frac{\partial \sigma_{y z}}{\partial z} \\
\rho \ddot{z}=\frac{\partial \sigma_{z x}}{\partial x}+\frac{\partial \sigma_{z y}}{\partial y}+\frac{\partial \sigma_{z z}}{\partial z}
\end{array}\right\}
$$

where is: $\ddot{x}, \ddot{y}, \ddot{z}$ - components of the vector of acceleration.

The stress tensor $\sigma_{i j}$ is separated into a hydrostatic component $p$ with the artificial viscosity $q$ and the deviator component $s_{i j}$ that is discussed more largely in $[16,17]$ :

$$
\left.\begin{array}{c}
\sigma_{x x}=-(p+q)+s_{x x} \\
\sigma_{y y}=-(p+q)+s_{y y} \\
\sigma_{z z}=-(p+q)+s_{z z} \\
\sigma_{x y}=s_{x y} \\
\sigma_{y z}=s_{y z} \\
\sigma_{z x}=s_{z x}
\end{array}\right\}
$$

The negative sign for the hydrostatic pressure $p$ follows from the usual notion that stresses are positive in tension and negative in compression. The strain tensor $\varepsilon_{i j}$ is determined from the relation between the strain rates and the velocities $(\dot{x}, \dot{y}, \dot{z})$ :

$$
\left.\begin{array}{c}
\dot{\varepsilon}_{x x}=\frac{\partial \dot{x}}{\partial x} \\
\dot{\varepsilon}_{y y}=\frac{\partial \dot{y}}{\partial y} \\
\dot{\varepsilon}_{z z}=\frac{\partial \dot{z}}{\partial z} \\
\dot{\varepsilon}_{x y}=\frac{1}{2}\left(\frac{\partial \dot{x}}{\partial y}+\frac{\partial \dot{y}}{\partial x}\right) \\
\dot{\varepsilon}_{y x}=\frac{1}{2}\left(\frac{\partial \dot{y}}{\partial z}+\frac{\partial \dot{z}}{\partial y}\right) \\
\dot{\varepsilon}_{z x}=\frac{1}{2}\left(\frac{\partial \dot{z}}{\partial x}+\frac{\partial \dot{x}}{\partial z}\right)
\end{array}\right\}
$$

These strain rates are related to the rate of the change of the volume $\dot{V} / V$ by:

$$
\frac{\dot{V}}{V}=\dot{\varepsilon}_{x x}+\dot{\varepsilon}_{y y}+\dot{\varepsilon}_{z z}
$$

The elastic behavior of metallic materials is determined by the Hook's Law relations between the deviator of stress rates and the strain rates. A pragmatic approach in the choice of yield criteria is a formulation given by the Von Misses yield criterion that describes the elastic limit and transition to the plastic flow. The applied criterion, determined by the principal stresses $\sigma_{1}, \sigma_{2}$ and $\sigma_{3}$, defines the local yield condition as follows:

$$
\left(\sigma_{1}-\sigma_{2}\right)^{2}+\left(\sigma_{2}-\sigma_{3}\right)^{2}+\left(\sigma_{3}-\sigma_{1}\right)^{2}=2 Y^{2}
$$

where is: $Y$ - the yield strength in simple tension.

The pressure $p$ is related to the density $\rho$ and specific internal energy $e$ through the EOS given in the general form $p=f(\rho, e)$. Different forms of the EOS are described in [16] and they must be solved simultaneously with the equation expressing the conservation of energy:

$$
\begin{aligned}
\dot{e}= & \frac{1}{\rho}\left(\sigma_{x x} \dot{\varepsilon}_{x x}+\sigma_{y y} \dot{\varepsilon}_{y y}+\sigma_{z z} \dot{\varepsilon}_{z z}+2 \sigma_{x y} \dot{\varepsilon}_{x y}\right. \\
& \left.+2 \sigma_{y z} \dot{\varepsilon}_{y z}+2 \sigma_{z x} \dot{\varepsilon}_{z x}\right) .
\end{aligned}
$$

Relative to the energetic materials a standard JonesWilkins-Lee (JWL) EOS $[16,18]$ was used to describe the adiabatic expansion of detonation products. The next equation represents the pressure as a function of the specific volume and energy:

$$
p=A\left(1-\frac{\omega \eta}{R_{1}}\right) e^{-\frac{R_{1}}{\eta}}+B\left(1-\frac{\omega \eta}{R_{2}}\right) e^{-\frac{R_{2}}{\eta}}+e \omega \eta
$$

with the following notation: $\eta=\rho / \rho_{e}-$ ratio of density of detonation products and explosive charge and $e$ - energy of detonation per volume unit. The values of constants $A, R_{1}, B, R_{2}$, and $\omega$ for very common explosives have been determined from dynamic experiments (cylinder test).

Used to model materials, typically metals, subjected to large strains, high strain rates and high temperatures, the Johnson Cook strength equation $[18,19]$ defines the yield stress, $Y$, as a function of strain, strain rate and temperature:

$$
Y=\left[A+B \varepsilon_{p}^{n}\right]\left[1+C \log \dot{\varepsilon}_{p}^{*}\right]\left[1-T_{H}\right]
$$

with the following notation: $\varepsilon_{p}$ - effective plastic strain; $\dot{\varepsilon}_{p}^{*}$ normalized effective plastic strain rate; $A, B, C, m$ and $n$ constants of material determined experimentally and available in the solver materials library, $T_{H}$ - homologous temperature $T_{H}=\left(T-T_{\text {ref }}\right) /\left(T_{\text {melt }}-T_{\text {ref }}\right)=(T-300) /\left(T_{\text {melt }}-300\right) \mathrm{K}$.

The Eq. (9) in the first set of the brackets represents the effect of strain hardening and gives the stress as a function of strain when $\varepsilon_{p}^{*}=1.0$ and $T_{H}=0$ (i.e. for experiments at the room temperature). The expressions in the second and third sets of the brackets represent the effects of strain rate and temperature, respectively. In particular, the latter relationship models the thermal softening so that the yield stress drops to zero at the melting temperature $T_{\text {melt }}$. The constants in these expressions were obtained by Johnson and Cook empirically by the means of dynamic Hopkinson bar tensile tests [20] over a range of temperatures. As well, the constants of the material were checked by calculations of the Taylor tests [21] of impacting metal cylinders on the rigid metal targets which provided strain rates in excess of $10 \mathrm{E}+5 \mathrm{~s}^{-1}$ and strains in excess of 2.0.

\section{Model of the casing crack}

When the high explosive charge detonates in a metallic cylinder (here a projectile casing), several things occur. First, 
a detonation wave propagates along the axis of the detonation (Fig.3). These results in the pressure generated with the attendant stress and strain wave [22] being transferred to the metallic casing.

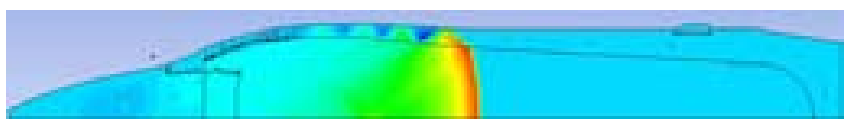

Figure 3. 2D model of the detonation wave propagation through explosive and the radial expansion of projectile casing $\left(t_{20}=20 \mu \mathrm{s}\right)$

Further, the casing expands and, affected by a complex pressure field that generates the involved shock and expansion waves, after some time ruptures by a shear or tearing failure. If the case expands significantly and removes significant energy from the detonation products, there is a condition known as a "terminal detonation". If the case expands very little before fragmenting, the result is known as a "prompt detonation". Once the case ruptures, fragments fly in directions dependent upon the initial rejection angle and velocity and their individual mass and geometry.

There are several factors that affect the fragmentation process: explosive brisance, charge to casing mass ratio, casing diameter, casing wall thickness and mechanical properties of the casing material, initiation, etc.

Different approaches in system integrity studying the classical mechanics problems, relating to continuum damage mechanics $[23,24]$ and classical fracture mechanics concepts $[25,26]$, are applied in explaining the phenomenological mapping of the crack initiation and propagation for different materials. So, the quasi-static fracture of linear elastic-plastic and linearly viscoelastic materials are quite well understood. On the other side, the involved very complex shock wave stresses initiate the dynamic fragmentation of the casing. Dynamic fragmentation is a spatially and temporally discrete process governed by material flaws (inherent and random), material properties (e.g., toughness, hardness, elastic and rupture stress and strain limits) and structure (e.g., grain type, size and orientation) [27].

The casing fragmentation usually begins from the outside diameter through the formation of sharp radial cracks of the longitudinal orientation. These cracks then join with shear cracks from the inside of the material (or not, if the material is extremely brittle). The cracks then coalesce into long, longitudinal cracks. If the casing material is resilient enough, as the casing expands radially and during this process, the wall will somewhat thin out. In any case, sooner or later, the metallic casing will fragment completely. The described scheme of casing fragmentation is depicted in Fig.4.

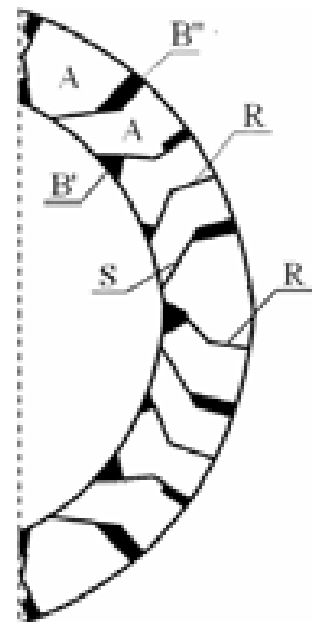

Figure 4. Scheme of casing wall rupture and fragments generating: (A) principal and (B) seed fragments
In the general case, regarding the morphology, two types of fragments arise [11,18,28]: large massive or principal fragments (A Type) and small light or seed fragments (B Type). The massive fragments comprise both casing surfaces from the inner and outer side and they are generated by principal stresses. On the other hand, the small fragments comprise one external surface (outer or inner) only. The variety of small fragments includes two subtypes (Fig.5): B' - the fragments of the explosive contact zone formed by shear cracks and B" - the fragments of the outer casing zone formed by the sharp rupture along the radial direction (typical for high-carbon steel).

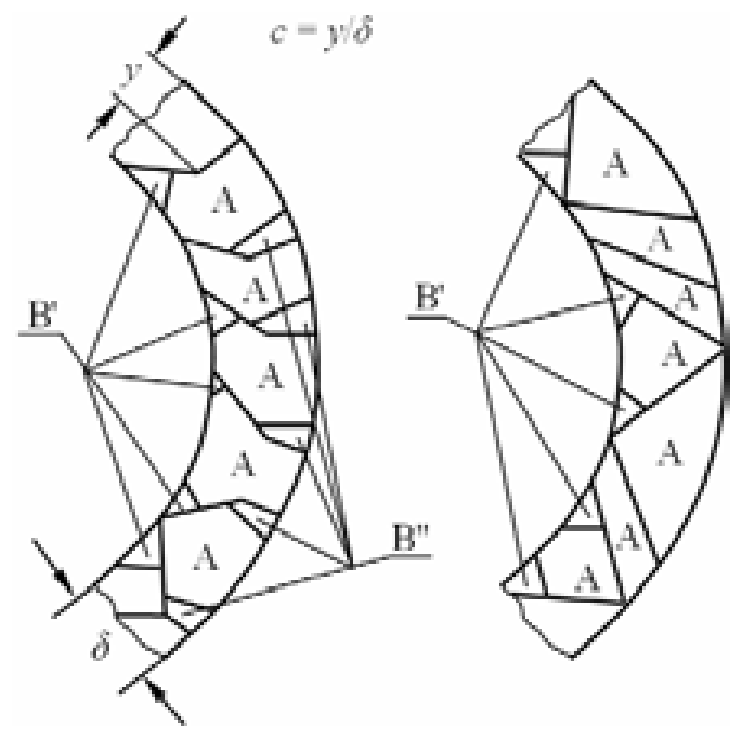

Figure 5. Casing crack scheme: brittle steel (left) and ductile steel (right)

The crack surfaces of principal massive fragments are characterized by two zones: the surfaces of brittle normal disruption (zone R in Fig.4) adjacent to the outer surface of the fragment and the surface of shear cracking along the sliding region (zone S in Fig.4) adjacent to the inner fragment surface.

Denoting the zone of the brittle normal disruption $y$ and wall thickness $\delta$, then the type of cracking can be described by the ratio $c=y / \delta$. E.g., for the fragments of brittle materials such as gray cast iron, the typical values of $c$ are between 0.5 and 0.8 . For low-carbon steels and alloy steels, a fragment generating occurs according to the scheme of a shear crack and $c \approx$ 0 (Fig.5, right). Beside the negative effect of high carbon contents, the mass of massive to small fragments ratio is directly proportional to the relative casing thickness and takes the values from 0.49 (thin-wall casing) to 0.91 (thick-wall casing) and more.

Furthermore, real fragmentation sand pit tests show that some metal mass of ruptured projectiles will be lost permanently for further analysis. In practice, the mass of so-called lost fragments [28] may take the allowed value up to 5\% of the total mass of metal. It contains primarily very fine fragments (particles 0.5 to $500 \mathrm{mg}$ of mass).

\section{Stochastic failure and statistical distributions of fragments} mass

To model the dynamical fragmentation for axis-symmetric loading and geometry, it is necessary to impose some material heterogeneity. Real materials have inherent microscopic flaws which cause failures and cracking to initiate. An approach to reproducing this numerically is to randomize the failure stress or strain for the material. Using this property, a Mott distribution $[5,6,12]$ is used to define the variance in failure stress or strain. The Mott model assumes that elementary probability of an un- 
fractured specimen of the unit length will fracture when the strain increase from $\varepsilon$ to $(\varepsilon+\mathrm{d} \varepsilon)$ takes the exponential form:

$$
C e^{\gamma \varepsilon} d \varepsilon
$$

where $\varepsilon$ is the strain, and $C$ and $\gamma$ are the parameters of the material.

With the experimentally determined fracture stress $\sigma_{F}$ and the strain $\varepsilon_{F}$, and the parameter in the strain-hardening law $\sigma_{P}$, the stochastic variance $\gamma$ and parameter $C$ will take an approximate form [6] as follows:

$$
\gamma \approx 160 \frac{\sigma_{P}}{\sigma_{F}\left(1+\varepsilon_{F}\right)} ; \quad C \approx \gamma e^{-(\varepsilon \gamma+0.5772)}
$$

In accordance with the assumed model, each element of the casing is allocated a value of the fracture probability $p$, determined by the Mott distribution, where the value of one is relevant to the mechanical characteristics of the material. The Mott probability of fracture $p$ distribution takes the form:

$$
p=1-\exp \left\{-\frac{C}{\gamma}[\exp (\gamma \varepsilon)-1]\right\}
$$

The stochastic failure option may be used in conjunction with many of the failure properties, including hydrodynamic pressure $\left(P_{\min }\right)$, plastic strain, principal stress, etc.

The numerous statistical distribution laws are applied to describe a real distribution of the HE projectile fragments. One of the earlier (Mott) and one of the recently proposed (Held) laws of the fragments mass distribution will be briefly discussed. In [12] Mott had formulated the well-known fragment distribution law in the form:

$$
N(m)=\frac{M_{0}}{2 \mu} \exp \left[-\left(\frac{m}{\mu}\right)^{0.5}\right] ; \mu=\frac{\bar{m}}{2} ; \quad \bar{m}=\frac{M_{0}}{N_{0}}
$$

- where is: $N(m)$ - the cumulative number of fragments or total number of fragments with the mass greater than $m, M_{0}$ the total mass of fragments, $N_{0}$ - the total fragment number and $\bar{m}$ - the average fragment mass .

Held [29] introduced the method to predict the cumulative mass of fragments $M(n)$ in terms of the cumulative number of fragments, $n\left(n=1,2,3, \ldots, N_{0}\right)$ :

$$
M(n)=M_{0}\left[1-\exp \left(-B n^{\lambda}\right)\right]
$$

In addition, the method of Held allowed an implicit form for the prediction of the fragment mass $m$, depending on the cumulative number of fragment:

$$
m=M_{0} B \lambda n^{\lambda-1} \exp \left(-B n^{\lambda}\right)
$$

Held constants $B$ and $\lambda$ are determined based on the obtained experimental data.

\section{Results and discussion}

\section{Numerical simulation of typical HE items}

In order to identify the end of the fragmentation process, the numerical integration of some of the models was controlled up to $200 \mu$ s time limit. The appropriate diagram of the overall fragmentation progress depending on time for $105 \mathrm{~mm}$ HE projectile, $120 \mathrm{~mm}$ HE mortar shell and $128 \mathrm{~mm}$ HE warhead is shown in Fig.6. The fragmentation progress, expressed in percents, represents the current fragments number $n_{f}$ to total fragments number ratio, $n_{f} / N_{0}$.

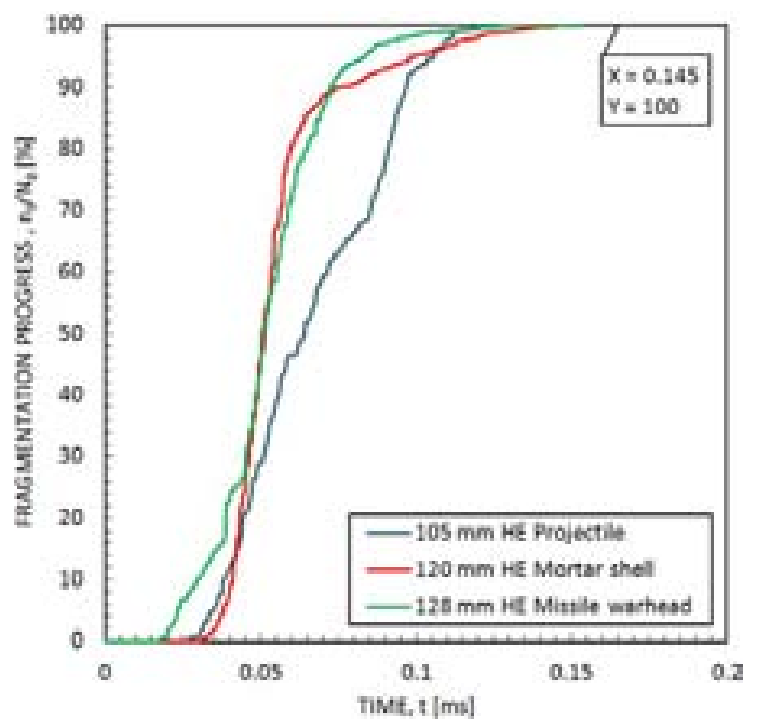

Figure 6. Fragmentation progress vs. time

Since the values of caliber are relatively narrow to each other, it is expected that the fragmentation processes will be completed at the approximately same time. This view is confirmed by a diagram in Fig.6, showing that the fragmentation in the most unfavorable case effectively ends after max $145 \mu$ s.

In addition, the visual illustrations of the simulated fragmentation process of the 3D models of all HE items (Table 2) loaded by the shock wave and pressure of gaseous products of detonation are given in Fig.7.

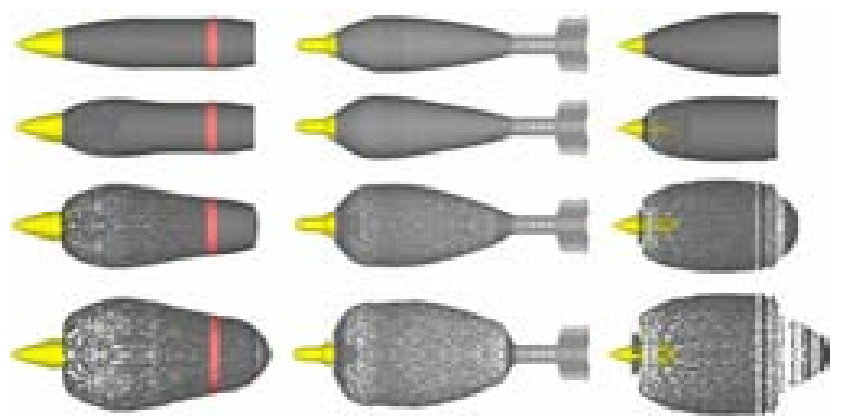

Figure 7. Illustrations of fragmentation process (from left to right): the 105 mm HE projectile M1, $120 \mathrm{~mm}$ HE mortar shell M62 and $128 \mathrm{~mm} \mathrm{HE}$ warhead M63 ( $t=0,30,60$ and $90 \mu \mathrm{s})$

In any case, the nose and tail sections will break up into a small number of relatively massive fragments. On the other hand, the ogival and cylindrical parts will fracture into many smaller fragments travelling at a high speed. Also, parallel numerical simulation and experiments indicated that the geometry of the casing base with the hemispherical inner side of the $105 \mathrm{~mm}$ HE projectile shows more favorable fragmentation behavior than the flat one.

Further, the numerical simulation is able to analyze the behavior of the fuze and the stabilizer of the detonated projectiles. The rejected fuze and stabilizer keep consistency after the detonation. Fig. 8 shows the time history of the velocity registered by two gauges (\#11 and \#12 in Fig.8) allocated on the front and the end side of the fuze body. In addition, the figure illustrates a typical appearance of the fragmented fuze $120 \mu$ s after initiation.

According to the diagram of velocities, after more oscillations the overall material of the fuze will take the final or socalled terminal velocity ( $300 \mathrm{~m} / \mathrm{s})$.

The behavior of mortar shell stabilizer follows the analog scenario taking very low terminal velocity, from 30 to $40 \mathrm{~m} / \mathrm{s}$. Because of a very low rate of rejection velocity that is ori- 
ented opposite to direction of the projectile falling velocity $(150-200 \mathrm{~m} / \mathrm{s})$, the massive mortar shell stabilizer frequently remains stuck in the ground when shooting is carried out at high elevation angles.

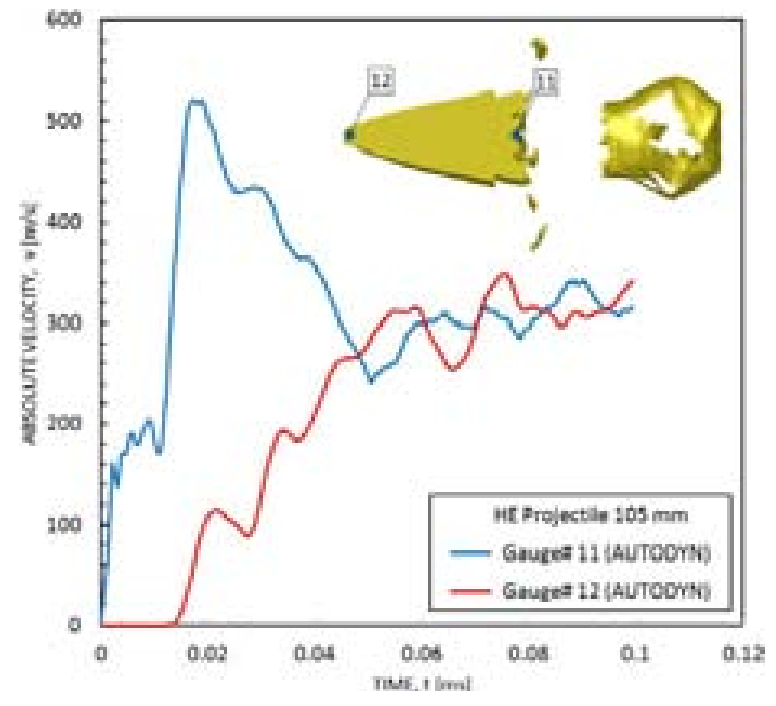

Figure 8. Time history of the velocity variation of fuze body

The calculated distributions of fragments velocities depending on the normalized origin- $X$ of all fragments for the $105 \mathrm{~mm}$ HE projectile, $120 \mathrm{~mm}$ HE mortar shell and $128 \mathrm{~mm}$ HE warhead are given in Figures 9-11, respectively. Here, the origin- $X$ means the initial position of the center of gravity (CG) of the fragment.

Figures 9-11 give very detailed information about fragments absolute velocity indicating the typical large variations of velocities at the end sides of the HE items. In the cases of the HE projectile and HE warhead, the velocities of the fragments generated from the flat end sections are varying from $350 \mathrm{~m} / \mathrm{s}$ up to $2300 \mathrm{~m} / \mathrm{s}$ [Figures 9 and 11]. On the other hand, the massive stabilizer of the HE mortar shell causes a sudden drop in velocity of the fragments generated from the end section of the projectile [Fig.10]. At once, the parallel numerical experiments of the mortar shell fragmentation without stabilizer showed that the fragments in this zone reach significantly higher velocities. E.g., in this case the fragments distributed around the axis of symmetry are traveling at speeds over $1000 \mathrm{~m} / \mathrm{s}$.

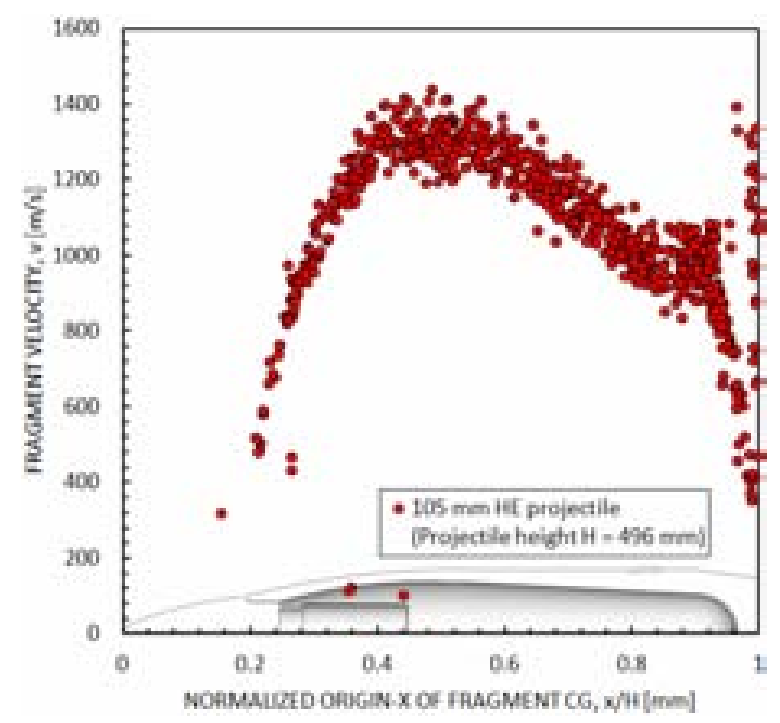

Figure 9. Fragments velocities of the $105 \mathrm{~mm}$ HE projectile vs. normalized origin- $X$

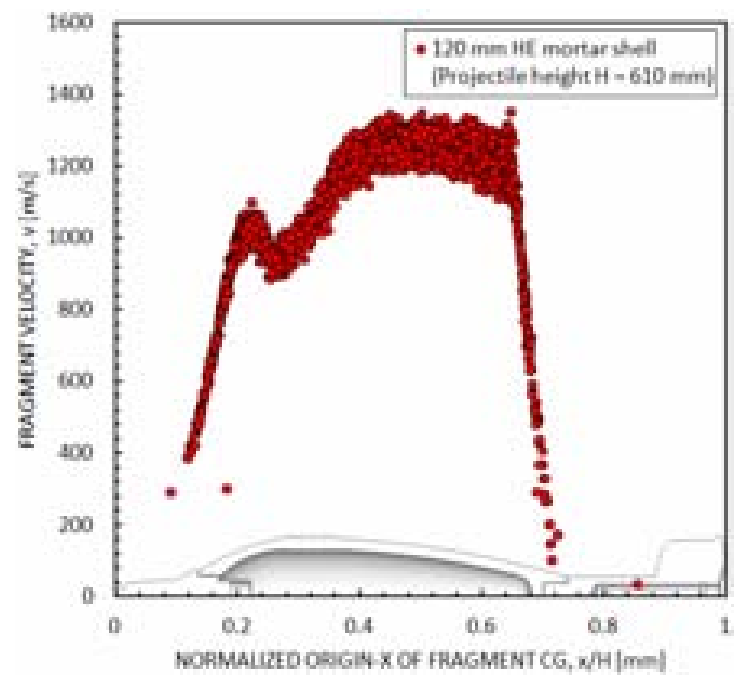

Figure 10. Fragments velocities of the $120 \mathrm{~mm}$ HE mortar shell vs. normalized origin- $X$

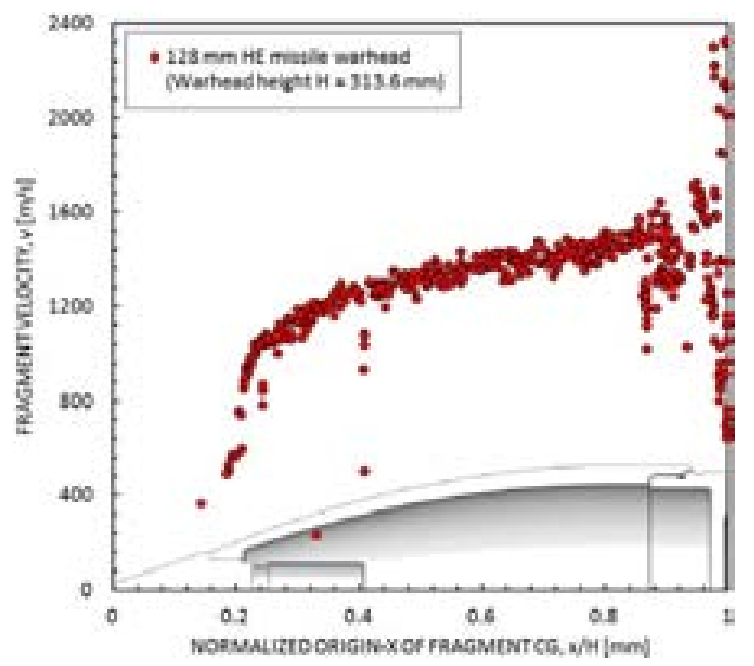

Figure 11. Fragments velocities of the $128 \mathrm{~mm}$ HE warhead vs. normalized origin- $X$

Regarding the theoretical analysis of the distribution of fragments mass here is considered only the fragmentation case-study of the $120 \mathrm{~mm}$ HE mortar shell (Fig.12).

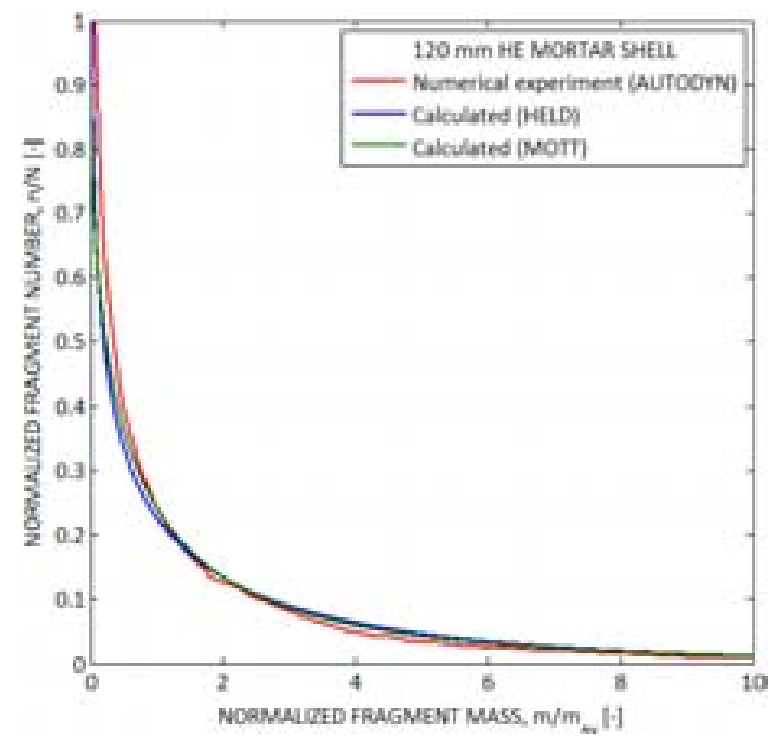

Figure 12. Distribution of the fragments mass of the $120 \mathrm{~mm}$ mortar shell

The theoretical distributions, illustrated in Fig.12, include simultaneously the results of the numerical simulation and 
fragmentation laws proposed by Mott and Held. The curves that represent the normalized fragment number depending on the normalized fragment mass (up to ratio $\mathrm{m} / \mathrm{m}_{a v}=\mathrm{m} / \overline{\mathrm{m}}=10$ ) match very well. Since the experimental data relating to the mass of the fragment cannot be classified individually fragment-byfragment as it enables the theory, the diagram in Fig.12 does not contain experimental data. So, the shown approach of presentation of the results does not provide a suitable comparative analysis of the numerical and experimental data.

To overcome the problem, in practice the fragments are classified into several mass fraction range. Such classification of the fragments still follows the sand pit tests. Similarly, the corresponding classification of the fragments mass, obtained by numerical experiments, was done for all HE items and shown in Table 4.

Table 4. Classification of the fragments mass given by numerical experiments

\begin{tabular}{|c|c|c|c|c|c|c|}
\hline \multirow{2}{*}{$\begin{array}{c}\text { Mass } \\
\text { fraction } \\
\text { label }\end{array}$} & \multicolumn{2}{|c|}{105 mm HE projectile } & \multicolumn{2}{|c|}{$\begin{array}{c}120 \text { mm HE mortar } \\
\text { shell }\end{array}$} & \multicolumn{2}{|c|}{$\begin{array}{l}128 \text { mm HE war- } \\
\text { head }\end{array}$} \\
\hline & $\begin{array}{l}\text { Mass frac- } \\
\text { tion } \\
\text { range }\end{array}$ & $\begin{array}{l}\text { Number } \\
\text { of frag- } \\
\text { ments }\end{array}$ & $\begin{array}{c}\text { Mass } \\
\text { fraction } \\
\text { range }\end{array}$ & $\begin{array}{c}\text { Number } \\
\text { of frag- } \\
\text { ments }\end{array}$ & $\begin{array}{c}\text { Mass frac- } \\
\text { tion } \\
\text { range }\end{array}$ & $\begin{array}{c}\text { Number } \\
\text { of frag- } \\
\text { ments }\end{array}$ \\
\hline 1 & $\begin{array}{c}0.0<m \leq \\
0.3\end{array}$ & 737 & $\begin{array}{c}0.0<m \leq \\
0.2\end{array}$ & 455 & $\begin{array}{c}0.0<m \leq \\
0.5\end{array}$ & 867 \\
\hline 2 & $\begin{array}{c}0.3<m \leq \\
0.5\end{array}$ & 342 & $\begin{array}{c}0.2<m \leq \\
1.0\end{array}$ & 2499 & $\begin{array}{c}0.5<m \leq \\
1.0\end{array}$ & 578 \\
\hline 3 & $\begin{array}{c}0.5<m \leq \\
1.0\end{array}$ & 402 & $\begin{array}{c}1.0<m \leq \\
2.0\end{array}$ & 721 & $\begin{array}{c}1.0<m \leq \\
2.0\end{array}$ & 391 \\
\hline 4 & $\begin{array}{c}1.0<m \leq \\
2.0\end{array}$ & 280 & $\begin{array}{c}2.0<m \leq \\
3.0\end{array}$ & 341 & $\begin{array}{c}2.0<m \leq \\
3.0\end{array}$ & 229 \\
\hline 5 & $\begin{array}{c}2.0<m \leq \\
3.0\end{array}$ & 166 & $\begin{array}{c}3.0<m \leq \\
5.0\end{array}$ & 292 & $\begin{array}{c}3.0<m \leq \\
5.0\end{array}$ & 200 \\
\hline 6 & $\begin{array}{c}3.0<m \leq \\
5.0\end{array}$ & 218 & $\begin{array}{c}5.0<m \leq \\
10\end{array}$ & 301 & $\begin{array}{c}5.0<m \leq \\
10\end{array}$ & 220 \\
\hline 7 & $5.0<m \leq 10$ & 266 & $\begin{array}{c}10<m \leq \\
20\end{array}$ & 95 & $\begin{array}{c}10<m \leq \\
15\end{array}$ & 50 \\
\hline 8 & $10<m \leq 15$ & 112 & \begin{tabular}{|c}
$20<m \leq$ \\
30 \\
\end{tabular} & 29 & $\begin{array}{c}15<m \leq \\
20 \\
\end{array}$ & 24 \\
\hline 9 & $15<m \leq 20$ & 76 & $\begin{array}{c}30<m \leq \\
50\end{array}$ & 8 & $\begin{array}{c}20<m \leq \\
30\end{array}$ & 12 \\
\hline 10 & $20<m \leq 30$ & 96 & $\begin{array}{c}50<m \leq \\
100\end{array}$ & 2 & $\begin{array}{c}30<m \leq \\
50\end{array}$ & 2 \\
\hline 11 & $30<m \leq 50$ & 31 & More & 2 & $\begin{array}{c}50<m \leq \\
70\end{array}$ & 2 \\
\hline 12 & $50<m \leq 75$ & 16 & - & - & More & 2 \\
\hline 13 & $\begin{array}{c}75<m \leq \\
100\end{array}$ & 4 & - & - & - & \\
\hline 14 & More & 2 & - & - & - & \\
\hline Sum & \begin{tabular}{|c|} 
Computed \\
(Experiment)
\end{tabular} & $\begin{array}{l}2748 \\
(2184)\end{array}$ & - & $\begin{array}{c}4743 \\
(3637)\end{array}$ & - & $\begin{array}{l}2577 \\
(2480)\end{array}$ \\
\hline
\end{tabular}

Table 4 contains data relating to the mass fraction label, relevant mass fraction range and number of fragments in the mass fraction range including all metallic parts (fuze, rotating band and stabilizer). The last row in the table shows that the total number of fragments obtained by the numerical experiment is always greater than the number of fragments obtained by the real experiment. Such a situation is caused by the loss of very small fragments during send pit tests, as was expected and what was discussed in the previous part of the paper.

The computed results given in Table 4 and appropriate experimental data $[7,8,30]$ are used for their comparative analysis and evaluation of the FEM as a predictive technique in the characterization of the HE projectile fragmentation. In this order, the comparative diagrams that represent the number fragment frequency, i.e. number of fragments in the mass fraction range are designed. The mass fraction range is labeled from 1 to $M$, where is: $M=14$ for the $105 \mathrm{~mm} \mathrm{HE}$ projectile, $M=11$ for the $120 \mathrm{~mm}$ HE mortar shell and $M=$ 12 for the $128 \mathrm{~mm}$ HE warhead. Together with the results of numerical simulation and real experiments, shown in Figures 13-15, the diagrams depict data calculated by the Held method.

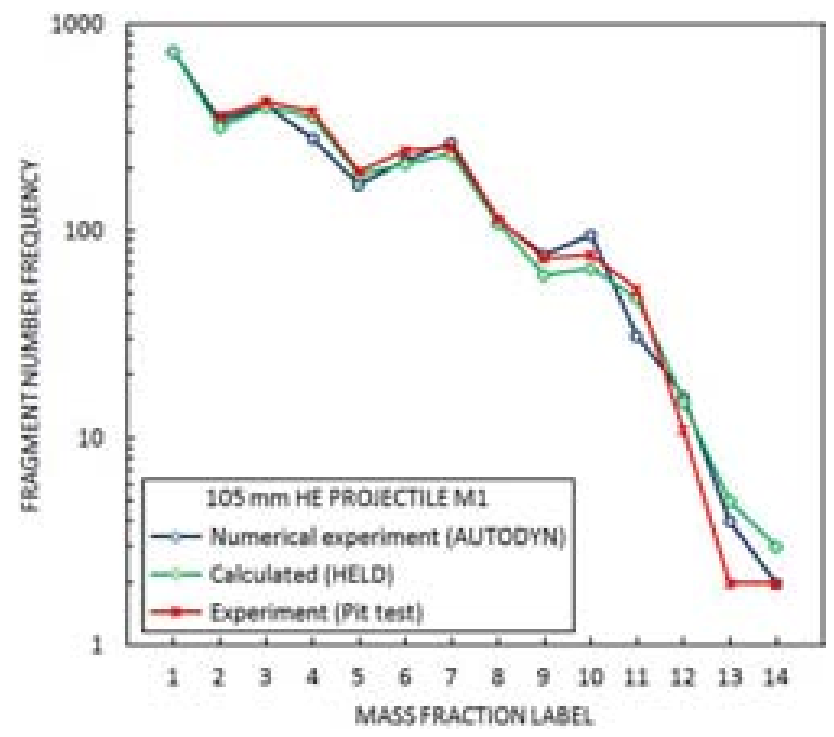

Figure 13. Fragments mass distribution of the $105 \mathrm{~mm}$ HE projectile

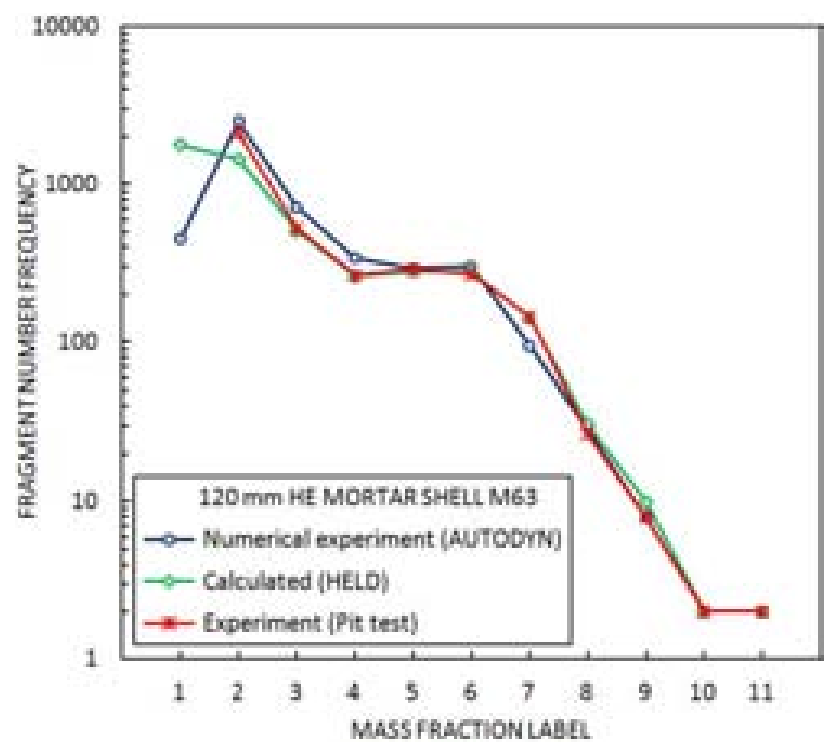

Figure 14. Fragments mass distribution of the $120 \mathrm{~mm}$ HE mortar shell

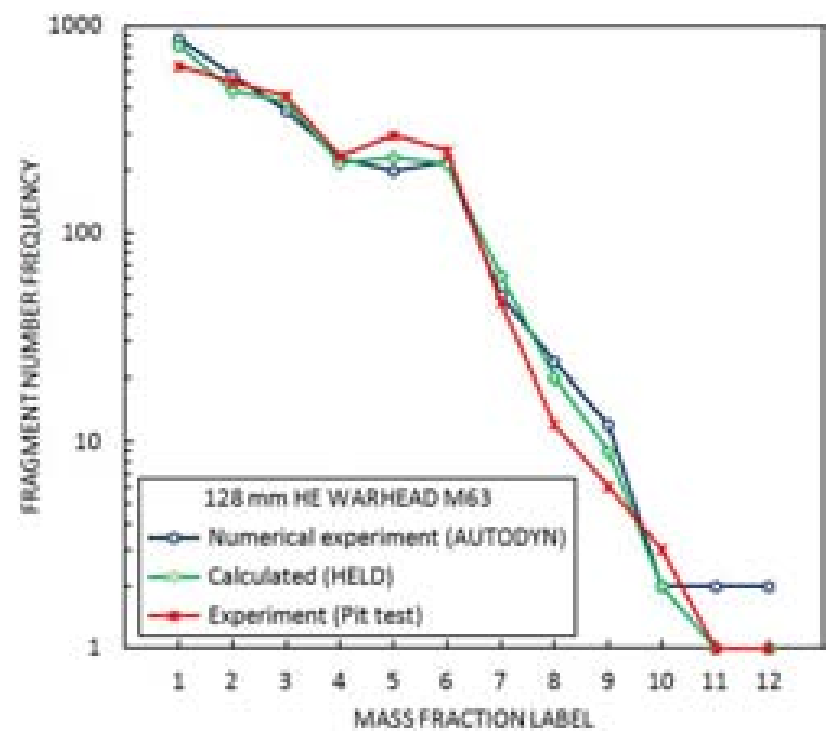

Figure 15. Fragments mass distribution of the $128 \mathrm{~mm}$ HE warhead 
In any case, according to Figures 13-15, all distributions of the fragment number frequency depending on the mass fraction range coincide very well, except for extremely low mass of fragments $(\mathrm{m} \leq 0.5 \mathrm{~g})$. This discrepancy, between the theoretical and experimental results, appears chiefly due to the lost fragments that are always present in the real tests. Regarding the deviations in extremely high fragments mass, the massive components like the fuze and stabilizer may cause some variations of the overall distributions, but this is not of a great importance. A comparative analysis of presented experimental and numerical results including the detailed researches of the effects of design parameters of the projectile, given in [2831 , clearly indicates the validity and the great benefits of the applied numerical methods based on the FEM and confirms that it is suitable for a high-quality-analysis of the natural fragmentation of all types of the real HE items.

\section{Determining the immeasurable fragmentation parameters}

As previously mentioned, a standard measure concepts in mechanics [32] and measure techniques used in dynamical tests $[20,21,33]$ cannot be applied successfully to measure e.g., parameters of deformation in the wall of the real expanded casing. However, the actual computation technique represents a powerful instrument for efficiently recording (computing) the various physical parameters of the considered explosive process that are immeasurable in real experiments: the plastic strain, strain rate, temperature, fragment velocity vectors and parameters of kinetic energy transfer in the wall of the 3D casing model.

Some kinds of such parameters of the expanded steel casing of the $120 \mathrm{~mm}$ HE mortar shell, affected by the detonation of TNT at $t_{40}=40 \mu \mathrm{s}$ and $t_{50}=50 \mu \mathrm{s}$, are illustrated in Fig.16 and discussed below.

The reached values of the plastic strain are extremely high (Fig.16a), up to the value of $\varepsilon_{p}=1.121\left(t_{50}=50 \mu \mathrm{s}\right)$. At the given moment, the wall of the casing base is intensively stressed due to the involved perpendicularly directed shock wave. The strain rate distribution of the projectile casing is given in Fig.16b. The maximum computed value $\dot{\varepsilon}_{p}=$ $7.195 \mathrm{E}+5 \mathrm{~s}^{-1}$ of the strain rate here is reached on the casing base as well. The temperature is distributed according to Fig.16c. It is ranged from the ambient temperature $300 \mathrm{~K}$ on the unloaded casing base and stabilizer to the maximum local temperature of $1075 \mathrm{~K}$ on the expanded cylindrical parts of the casing. Finally, Fig.16d depicts the vector velocity distribution of fragments and unfragmented elements of the casing. According to the last illustration, some particles of the projectile casing intensively accelerate until the instantaneous velocity of $1188 \mathrm{~m} / \mathrm{s}$.
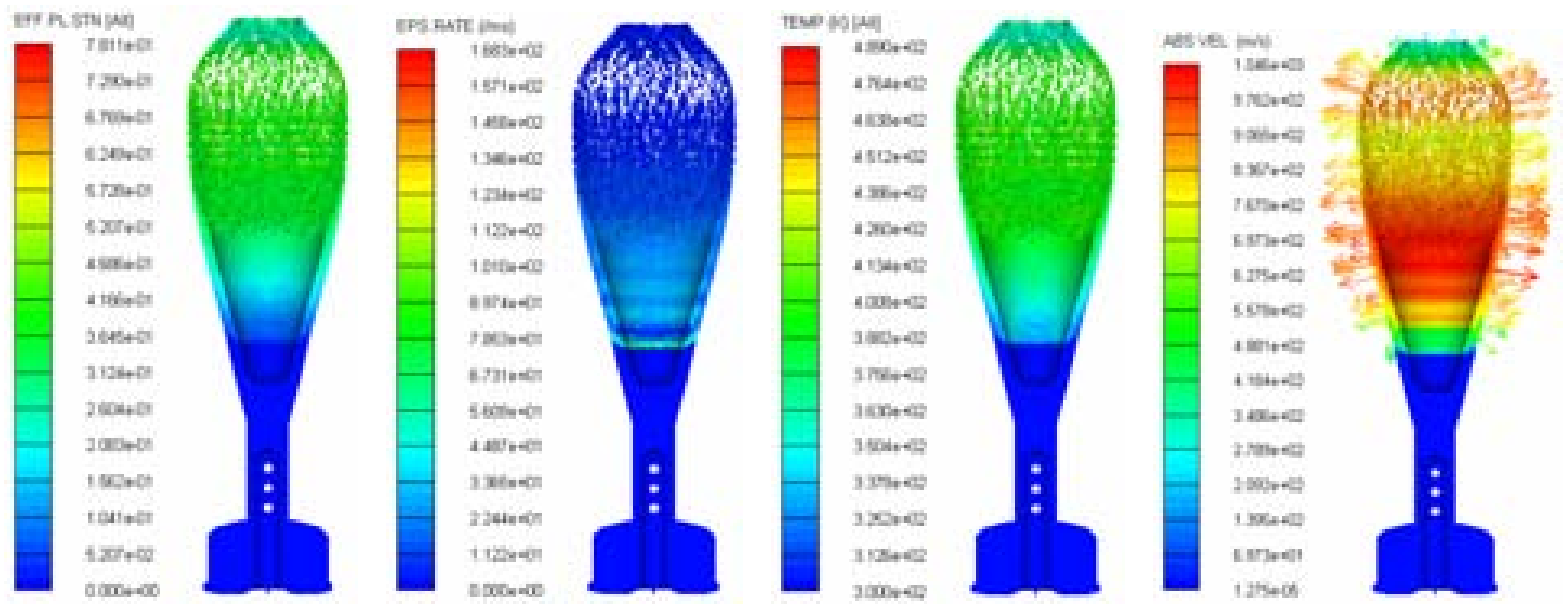

$t_{40}=40 \mu \mathrm{s}$

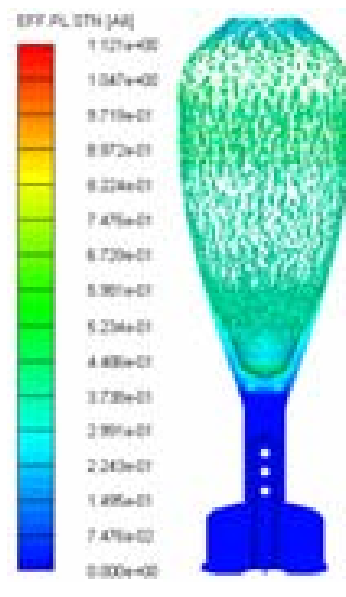

a)

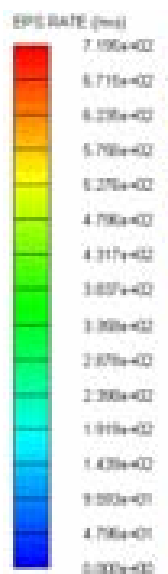

sames

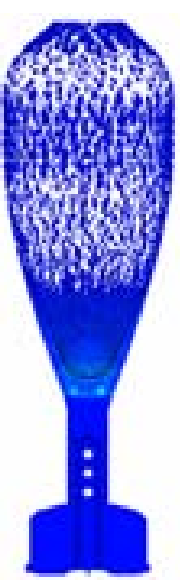

b)

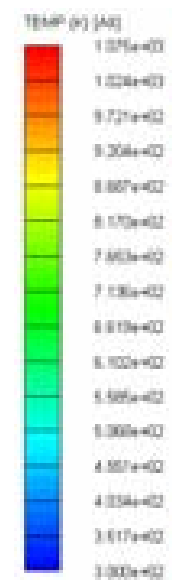

$t_{50}=50 \mu \mathrm{s}$

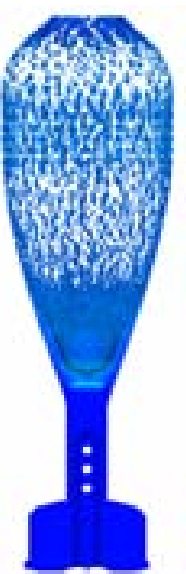

c)

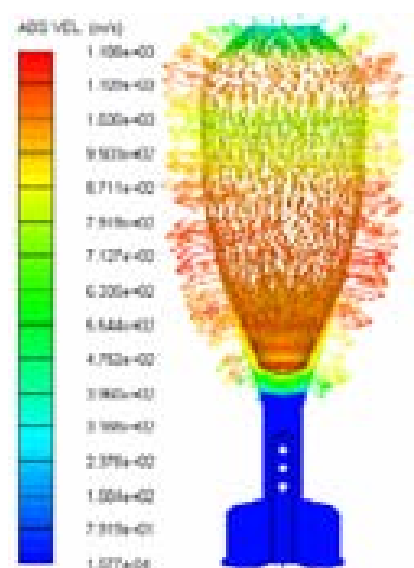

d)

Figure 16. Physical parameters of the $120 \mathrm{~mm}$ HE mortar shell fragmentation: a) Plastic strain, b) Strain rate, c) Temperature and d) Fragments velocity

In addition, the velocity was registered in more gauge points located along the casing. The time history of acceleration and oscillatory velocity increasing in more opposite points on the inner and outer side of the casing wall is given in Fig.17. 


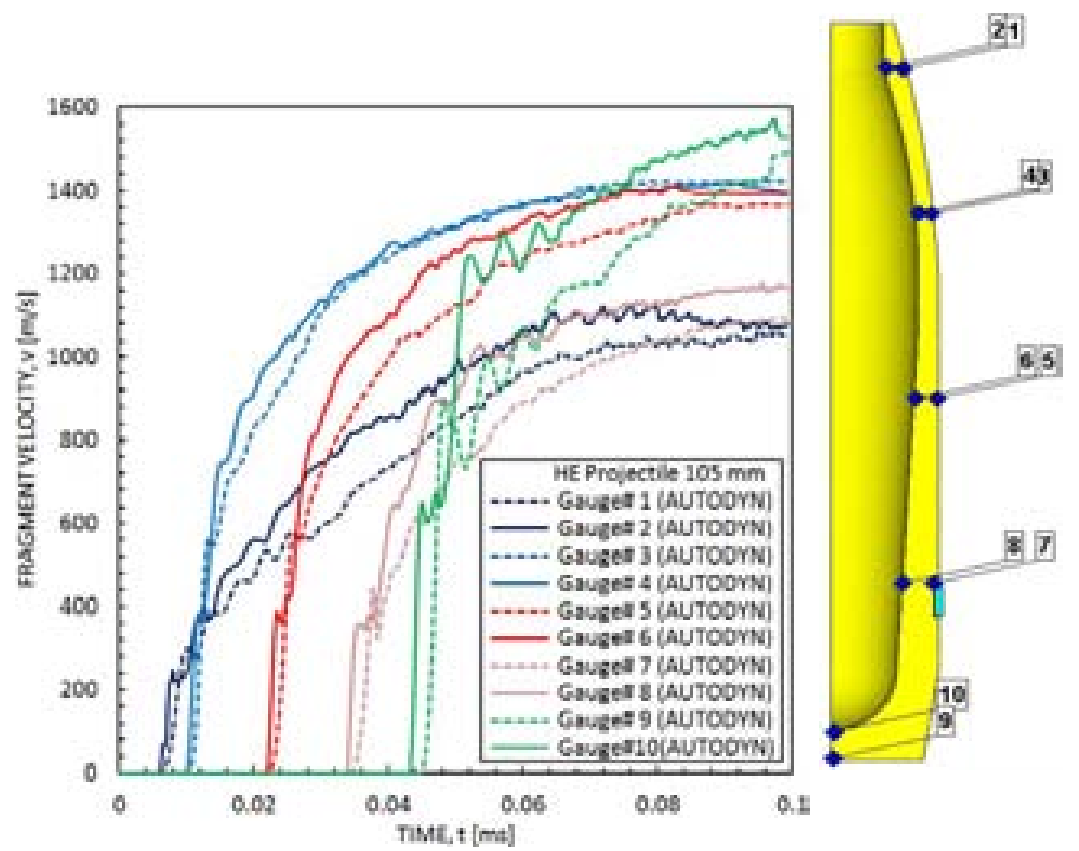

Figure 17. Time history of the velocity variation on the inner and outer side of the casing, with gauge points allocation (Case \#5)

The accomplished additional analyses confirm another excellent performance of the solver used in the numerical simulation of the projectile fragmentation. Regarding the FEM based numerical software, its main disadvantage is the impossibility of introducing the effect of the chemical composition of the casing materials (iron and shell-grade steels) in the analysis of the fragmentation process. One possible way to overcome it is by artificially adjusting one (or more) of the mechanical parameters of the casing material.

Finally, we have to emphasize that this paper has demonstrated the great possibilities of the techniques based fully on the FEM and stochastic failure theory in solving one of the most complex problems of the explicit dynamics such is the fragmentation of detonating projectile.

\section{Conclusion}

Numerical simulation of the casing fragmentation of more specific types of the HE projectiles enables determining the main characteristics of fragmentation, relating primordially to the fragments velocity and fragments mass distributions. The comparative analysis of the calculated data and appropriate experimental results of the fragmentation coincide well, confirming the validity of the applied numerical technique based on the FEM approach. The numerical simulation of the fragmentation process varying the mechanical characteristics of the casing and type of filled explosive was successfully carried out. The present computation method is able to determine a large variety of the parameters of fragmentation such as the fragment velocity, fragment size and mass and fragment mass distribution. Furthermore, a few characteristics of casing fragmentation, immeasurable in real experiments, are computed and shown, e.g., the temperature, stress and strain and strain rates in the casing wall.

\section{Acknowledgement}

Parts of this research were supported by the Ministry of Education, Science and Technological Development of the Republic of Serbia through the Mathematical Institute SANU Belgrade Grant OI174001 " - Dynamics of hybrid systems with complex structures. Mechanics of materials". The author would like to thank Dr Milan Bojanović, Director of CAD PROFESSIONAL
SYS, for his support of the research and for facilitating the use of the licensed academic software ANSYS products.

\section{References}

[1] PETROVIĆ,M.: Elements of mathematical phenomenologyy, Serbian Royal Academy, Printing by Planeta, Belgrade, 1911. (in Serbian)

[2] PETROVIĆ,M.: Phenomenological mapping, Serbian Royal Academy, Printing by Planeta, Belgrade, 1933. (in Serbian)

[3] HEDRIH (Stevanović),K.: Measurements of Dynamical System Integrity and Fracture Mechanics, Monograph Fracture of Nano and Engineering Materials and Structures, edited by E. Gdoutos, DOI: 10.1007/1-4020-4972-2_392, ISBN 978-1-4020-4971-2 (Print) 978-14020-4972-9 (Online), Springer, 2008, pp. 793-794

[4] DEHN,J.: Probability formulas for describing fragment size distribution, Ballistic research laboratory, Aberdeen Proving Ground, ARBRL-TR-02332, 1981.

[5] GRADY,D.E.: Investigation of explosively driven fragmentation of metals-two-dimensional fracture and fragmentation of metal shells, Progress Report II, US. Department of Energy, Lawrence Livermore National Laboratory, UCRL-CR-152264, B522033, 2003.

[6] ELEK,P., JARAMAZ,S.: Fragment mass distribution of naturally fragmenting warheads, FME Transactions, Faculty of Mechanical Engineering, Belgrade, 2009, Vol.37, pp. 129-135.

[7] VUKAŠINOVIĆ,M.: Contribution to theory and practice of the experimental testing of fragmentation effect of the high explosive projectiles, PhD dissertation, Military Technical Academy, Belgrade, 1999. (in Serbian)

[8] JOVANOVIĆ,R.: Evaluation of regularity of HE projectiles fragmentation using statistical tests, MSc thesis, Faculty of Mechanical Engineering, University of Belgrade, Belgrade, 2002. (in Serbian)

[9] ELEK,P., JARAMAZ,S.: Modeling of fragmentation of rapidly expanding cylinders, Theoret. Appl. Mech., Belgrade, 2005, Vol.32, No.2, pp. 113-130.

[10] CRULL,M., SWISDAK,M.: Methodologies for calculating primary fragment characteristics, Technical Paper, No.16, Department of Defense Explosives Safety Board Alexandria, VA, 2005.

[11] ORLENKO,L.P. (ed.): Physics of explosion, Third edition, revised and supplemented, Edited by the publishing house "Nauka", Home Edition of physical and mathematical literature, Moscow, 2004. (in Russian)

[12] MOTT,N.F., LINFOOT,E.H.: A theory of fragmentation, British Ministry of Supply Report, AC 3348, 1943.

[13] ĐURĐEVAC,D.: Possibility of the FEM application for a stress condition analysis of an artillery projectile body, Scientific Technical Review, ISSN 1820-0206, 2008, Vol.58, No.1, pp. 3-8.

[14] GOLD,V.M., BAKER,E.L., POULOS,W.J.: Modeling fragmentation performance of natural and controlled fragmentation munitions, 23rd International Symposium on Ballistics, Tarragona, Spain, 2007, pp.16-20. 
[15] GOLD,V.M., BAKER,E.L., POULOS,W.J., FUCHS,B.E.: PAFRAG modeling of explosive fragmentation munitions performance, International Journal of Impact Engineering, Elsevier, 33, 2006, pp. 294-304.

[16] www.century-dynamics.com and www.ansys.com, Theory manual, Century Dynamics, Solutions through Software, Huston, USA.

[17] TEMAM,R., MIRANVILLE,A.: Mathematical modeling in continuum mechanics, Second edition, Cambridge University Press The Edinburgh Building, Cambridge UK, Published in the USA by Cambridge University Press, New York, 2005.

[18] CARLEONE,J. (ed.): Tactical missile warheads, American Institute of Aeronautics and Astronautics, Washington DC, 1993.

[19] JOHNSON,G.R., COOK,W.H.: A constitutive model and data for metals subjected to large strains, high strain rates and high temperatures, Proceedings of 7th international symposium on Ballistics, The Hague, The Netherlands, 1983, pp. 557-564.

[20] NICHOLAS,T.: Dynamic tensile testing of structural materials using a split Hopkinson bar apparatus, Technical report AFWAL-TR-80-4053, Materials Laboratory, USA, 1980.

[21] HOUSE,J.W.: Taylor impact testing, Technical Report AFATL-TR-8941, University of Kentucky, Lexington, Kentucky, USA, 1989.

[22] PORUBOVA,A.V., PASTRONEC,F.: Non-linear bell-shaped and kink-shaped strain waves in microstructured solids, International Journal of Non-Linear Mechanics, Elsevier, 2004, Vol. 39, No.8, pp. 1289-1299.

[23] BONORA,N.: A nonlinear CDM model for ductile failure, Engineering Fracture Mechanics, Elsevier, 1997, Vol.58, No.1-2, pp. 11-28.

[24] BORDASA,S., RABCYUK,T., ZIC,G.:, Three-dimensional crack initiation, propagation, branching and junction in non-linear materials by an extended meshfree method without asymptotic enrichment, Engineering Fracture Mechanics, Elsevier, 2008, Vol.75, No.5, pp.943-960.
[25] BOLJANOVIĆ,S., MAKSIMOVIĆ,S., ĐURIĆ,M.: Analysis of crack propagation using the strain energy density method, Scientific Technical Review, ISSN 1820-0206, 2009, Vol.59, No.2, pp. 12-17.

[26] CARLUCCY,D., JACOBSON,S.: Ballistics - Theory and design of guns and ammunition, CRC Press, Taylor \& Francis Group, LondonNew York, 2008.

[27] HOGAN,J.D. et al.: Dynamic fragmentation of natural ceramic tiles: Ejecta measurements and kinetic consequences, International Journal of Impact Engineering, Elsevier, 58, journal homepage: www.elsevier.com/locate/ijimpeng , 2013, pp.1-16.

[28] UGRČIĆ,M.: Numerical simulation of the Fragmentation process of high explosive projectiles, Scientific Technical Review, ISSN 18200206, 2013, Vol.63, No.2, pp. 47-57.

[29] HELD,M.: Fragment mass distribution of HE projectile, Propellants, Explosives, Pyrotechnics, 1990, Vol. 15, No. 6, pp. 254-260,

[30] UGRČIĆ,M.: Fundamentals of projectile design and producing Examples with the theory abstracts, VIZ, Military Academy Belgrade, 2008. (in Serbian)

[31] TANAPORNRAWEEKIT,G., KULSIRIKASEM,W.: Effects of material properties of warhead casing on natural fragmentation performance of high explosive (HE) warhead, World Academy of Science, Engineering and Technology, 2011, Vol.59, pp.1275-1280.

[32] SETH,B.R.: Measure-concept in mechanics, International Journal of Non-Linear Mechanics, Elsevier, 1966, Vol.1, No.1, pp. 35-40.

[33] WANG,L., LABIBES,K., AYARI,Z., PLUVINAGE,G.: Generalization of split Hopkinson bar technique to use viscoelastic bars, International Journal of Impact Engineering, Elsevier, 1994, Vol.15, No.5, pp. 669-686.

Received: 22.10.2015. Accepted: 22.12.2015.

\title{
Karakterizacija prirodne fragmentacije razornih ubojnih sredstava primenom numeričke tehnike zasnovane na MKE
}

\begin{abstract}
Izložena nova metodološka procedura za kompletnu numeričku simulaciju razaranja košuljice integriše metodu konačnih elemenata i teoriju stohastičkog razaranja sadržane u solverima za 2D i 3D analizu osno-simetričnog modela fragmentacije projektila. Ovaj rad se fokusira na efekte uticaja tipa košuljice na karakteristike procesa fragmentacije. U tom cilju, odabrani uzorak razmatra tri specifične konstrukcije razornih ubojnih sredstava: razorni projektil $105 \mathrm{~mm}$ M1, razornu minobacačku minu 120 mm M62 i razornu bojnu glavu 128 mm M63 za raketni projektil. Takođe, prezentirana metodologija omogućava analizu uticaja mehaničkih svojstava materijala košuljice i tipa eksploziva na proces fragmentacije. Rezultati numeričke simulacije i određeni relevantni eksperimentalni podaci su iskorišćeni za njihovu komparativnu analizu i ocenu izložene numeričke metode, potvrđujući da izračunati parametri korektno opisuju karakteristike prirodne fragmentacije košuljice.
\end{abstract}

\section{Характеристики естественной фрагментации разрушительных смертоносных средств с использованием численных методов, основанных на MKE}

\begin{abstract}
Здесь представлена новая методологическая процедура для полного численного моделирования разрушения рубашки, которая интегрирует метод конечных элементов и теорию случайной стохастической деструкции, содержащиеся в решателе для 2D и 3D анализа аксиально-симметричной модели осколочных снарядов. В данной статье основное внимание уделяется воздействию типа рубашки на характеристики процесса фрагментации (разрушения на осколки). С этой целью, выбранный шаблон рассматривает три конкретных конструкций разрушительных боеприпасов: разрушительный снаряд $105 \mathrm{~mm}$ М1, разрушительный миномётный снаряд $120 \mathrm{~mm}$ М62 и разрушительную боеголовку $128 \mathrm{~mm}$ М63 реактивного снаряда. Кроме того, представленная методика позволяет анализ влияния механических свойств материалов рубашки и типа взрывчатых веществ на процесс фрагментации (разрушения на осколки). Результаты численного моделирования и некоторые соответствующие экспериментальные данные используются для их сравнительного анализа и оценки экспонированных численных методов, подтвердив, что вычисленные параметры правильно описывают характеристики естественной фрагментации рубашки.
\end{abstract}




\title{
Caractérisation de la fragmentation naturelle des moyens puissants meurtriers par l'utilisation de la technique numérique basée sur MEF
}

\begin{abstract}
La nouvelle méthodologie pour la simulation numérique complète de la destruction du corps de cartouche intègre la méthode des éléments finis (MEF) et la théorie de la destruction stochastique dans les solveurs pour l'analyse 2D et 3D du modèle axial symétrique de la fragmentation du projectile. Ce papier est centré sur les effets produits par le type du corps de cartouche sur les caractéristiques du processus de fragmentation. Dans ce but l'exemplaire choisi considère trois constructions spécifiques des moyens meurtriers puissants: projectile 105mm M1, mine de mortier 120mm M62 et ogive puissant 128mm M63 pour le projectile fusée. La méthodologie présentée permet aussi l'analyse des effets des propriétés mécaniques des matériaux du corps de cartouche et du type de l'explosif sur le processus de fragmentation. Les résultats de la simulation numérique et les données expérimentales relevantes ont été utilisés pour leur analyse comparative et pour l'évaluation de la méthode numérique présentée en confirmant que les paramètres calculés décrivaient correctement les caractéristiques de la fragmentation naturelle du corps de cartouche.
\end{abstract}

Mots clés: projectile puissant, fragmentation de projectile, simulation numérique, méthode de éléments finis. 